\title{
Occurrence of the alien zigzag elm sawfly, Aproceros leucopoda (Hymenoptera: Argidae), in arboretums and botanical gardens of Hungary
}

\section{GÁBOR VÉTEK ${ }^{1}$ \\ DÉNES BARTHA ${ }^{2}$ \\ RICHÁRD OLÁH ${ }^{1}$ \\ ${ }^{1}$ Szent István University, Department of Entomology, Villányi út 29-43, H-1118 Budapest, Hungary \\ ${ }^{2}$ University of West Hungary, Institute of Botany and Nature Conservation, Bajcsy-Zsilinszky u. 4, H-9400 Sopron, Hungary}

\section{Correspondence:}

Gábor Vétek

E-mail:Vetek.Gabor@kertk.szie.hu

Key words: invasive species; Argidae; distribution; Ulmus; damaged taxa

Received January 31, 2017.

Revised June 30, 2017.

Accepted July 03, 2017.

\begin{abstract}
Background and purpose: The invasive alien zigzag elm sawfly, Aproceros leucopoda (Hymenoptera: Argidae), native to East Asia, was identified as a new pest of elms (Ulmus spp.) in Europe in 2003. Following the first records in Poland and Hungary, it has been found in many other European countries. Plant taxa on which damage by larval feeding has been observed under natural conditions either in Asia or in Europe all belong to the genus Ulmus. Ulmus pumila (including var. arborea) seems to be a preferred host, but other species have also been reported as having suffered severe defoliation by the pest. One objective of our study was to complete information on the distribution of the sawfly species in Hungary. Moreover, we searched for Ulmus taxa which might be affected under natural conditions.
\end{abstract}

Materials and methods: To provide data on distribution and susceptible elms, we carefully checked Ulmus taxa for the presence of any juvenile developmental stages of $\mathrm{A}$. leucopoda and the characteristic feeding traces on leaves in 17 arboretums and botanical gardens throughout Hungary in 2011 and 2016.

Results and conclusions: We have recorded A. leucopoda or only the clear symptoms of damage by it at all the locations visited and totally on 20 Ulmus taxa. We have identified 14 of these for the first time as being susceptible to the pest. We suggest that the suitability for egg laying and sensitivity to at least partial damage by $\mathrm{A}$. leucopoda of the damaged taxa should be considered before planting them for any purposes.

\section{INTRODUCTION}

The invasive alien zigzag elm sawfly, Aproceros leucopoda Takeuchi,

1939 (Hymenoptera: Argidae), is of East Asian origin, and was first recorded in Poland and Hungary in Europe in 2003 (1). Since the first report of the pest from many Eastern and Central European countries by Blank et al. (1), it has been found to have extended its range to both the southern and western parts of the continent, as it has been summarized briefly by Vétek et al. (2). The limited number of data known from literature and indicating the countrywide distribution of the pest in Hungary are shown as a part of Figure 1 in the Results.

Aproceros leucopoda seems to be oligophagous on elms, Ulmus spp. (Ulmaceae) (1), although it cannot be excluded that the pest may also attack plant genera other than Ulmus (3). Parthenogenetically reproducing females of $A$. leucopoda insert their eggs into the edge of the leaf, 
and, after hatching, feeding traces of young larvae appear as characteristic zigzag patterns on the leaf blade $(1,4)$. Based on the work of Eiseman (5) and according to S. Blank (pers. comm.) the 'zigzag' feeding habit has hitherto been recorded only in A. leucopoda and some Sterictiphora species in Sterictiphorinae, but larvae of the studied S. prunivora and S. serotina were found feeding on Prunus spp. (Rosaceae) (5). Later, as A. leucopoda larvae grow, the affected leaf might be almost completely consumed. During the vegetation period, pupation takes place in a loosely spun cocoon attached to the lower surface of the leaf (remnant) or woody parts of the plant, but the cocoon might also be found on the ground $(1,4)$.

Damaged trees may belong to either non-native or native taxa of the genus Ulmus (1). So far, $U$. davidiana, $U$. pumila (including var. arborea), U. glabra, U. laevis and $U$. minor have been reported as significantly infested elms $(1,2,4,6,7,8,9,10,11,12,13,14,15,16,17,18)$. Some Resista hybrid elms have also been found as having been damaged considerably by the pest (19). In Table 1 we tried to review the reports on Ulmus taxa specimens of which have been identified as having suffered damage by the pest. In order to avoid speculations and confusions which may be unintended consequences of interpreting plant names written only in national languages, only those

Table 1. Ulmus taxa reported in literature as damaged by Aproceros leucopoda.

\begin{tabular}{|ll|}
\hline Damaged Ulmus taxon ${ }^{1}$ & References \\
\hline U. davidiana & 17,20 \\
$\begin{array}{l}\text { U. davidiana var. japonica } \\
\text { (syn.: } \text { U. japonica) }\end{array}$ & 1,19 \\
U. glabra & $1,7,18,19,21,22,23$ \\
Ulmus $\times$ hollandica (syn.: & 24 \\
U. glabra $\times$ U. minor) & \\
Ulmus $\times$ hollandica 'Belgica' & 25 \\
U. laevis & $1,7,8,26$ \\
U. minor & $1,7,12,15,18,19,21,22,23$, \\
(syn.: U. campestris) & $24,25,27,28,29$ \\
U. minor var. suberosa & 19 \\
U. minor 'Sarniensis' & 21 \\
U. minor 'Webbiana' & 19 \\
U. pumila & $1,2,6,7,8,9,10,11,12,13,14$, \\
U. pumila var. arborea & $17,18,20,22,23,30,31,32$ \\
Ulmus 'New Horizon' & $19,16,19,28$ \\
Ulmus 'Rebona' & 19 \\
Ulmus 'Regal' & 19 \\
Ulmus 'Resista' & 19 \\
\hline
\end{tabular}

${ }^{1}$ The synonym, based on the work of Mackenthun (33), is indicated in brackets if that name was used in any of the cited references. We did not check if the taxa named in the different publications have been identified correctly by the authors. sources are shown here in which the scientific name of the taxon was (also) given by the author(s).

Classification of elms remains problematic even today. Both the extensive natural hybridization and the artificial crossings in breeding programs have led to a high and often confusing diversity of forms which lack clear features for a convincing taxonomic differentation. As a result, there is no uniform and generally accepted system of elms actually (33). Nevertheless, recently published works by several authors (e.g. 33) may contribute to the transparency of the classification of elms and help us use the currently most acceptable taxon names.

One objective of our study was to complete information on the distribution of $A$. leucopoda in Hungary. Furthermore, by focusing our studies on arboretums and botanical gardens, not only additional records of the sawfly species but also data on various Ulmus taxa affected could be collected. Although besides Blank et al. (1) Vétek et al. $(4,16)$ have already published many presence records of the pest in Hungary, indicating also preliminary results of studies started in 2011 and carried out in arboretums and botanical gardens to get information on the occurrence of and taxa damaged by the pest (16), detailed data have not yet been published, and are presented in this paper.

\section{MATERIALS AND METHODS}

In 2011 and 2016, we visited totally 17 arboretums and botanical gardens located at various parts of Hungary (details are given in the Results) to collect data on the occurrence of $A$. leucopoda there. Based on the biology of the pest (see 1), we started the field survey in the middle of July so as to increase the chance of finding damaged elms. In each case, we carefully checked the Ulmus taxa found at a given site for the presence of any juvenile developmental stages of $A$. leucopoda and the characteristic feeding traces on leaves. We considered a record positive if a live stage of the species could be observed (e.g. an $A$. leucopoda larva feeding on the leaf or its pupa present in a cocoon attached to the leaf), but also if we could find only the characteristic feeding trace on an elm leaf, which latter in itself is considered to be a clear symptom of damage by this pest $(24,31)$. If we caught site of a zigzag feeding trace, we checked the symptoms thoroughly usually searching also for the remnants of the egg laid by the species (into the edge of the leaf). We did not regard any external injuries on leaves other than those showing the typical zigzag pattern as a proof of presence of $A$. leucopoda. Nevertheless, besides the feeding traces of the larvae (but without any live specimens), empty cocoons typical of the species, if also found, could serve as a confirmation of the record.

If we deemed the record positive, we collected a shoot sample of the damaged Ulmus taxon and we also made 
photos of the individual plant concerned in several cases to help the process of identification and for further documentation. Voucher specimens have been deposited in the Herbarium Institutum Botanicum Universitatis Soproniensis, Hungary. The label, if present, of an individual elm tree could be informative when we tried to confirm the identity of a taxon. We identified the Ulmus taxa by following the keys of Roloff et Bärtels (34) and Fu et al. (35). The scientific name of a given taxon we use in the Results is based on the combination of information from relevant handbooks and databases, especially Mackenthun (33), but also Bärtels et Schmidt (36), Roloff et Bärtels (34), Bannon et Hipp (37), Fu et al. (35), Schütt et al. (38), The International Plant Names Index (39), and The Plant List $(40)$.

\section{RESULTS}

Based on the already known presence records of $A$. leucopoda in Hungary completed with the results of our survey, the pest may be confirmed to be widely distributed throughout the country. We have managed to record A. leucopoda or only the clear symptoms of damage by it in all the 17 arboretums and botanical gardens we visited and totally on 20 different Ulmus taxa (Figure 1 and Table 2). (Note: The total number of Ulmus taxa as being 19 is an error in Vétek et al. (41).) We have found a comparatively wide range of botanical taxa belonging to Ulmaceae in the following collections: Diószegi Sámuel Botanikus Kert, Kecskeméti Arborétum, and Nemzeti Botanikus Kert, Vácrátót.

We have identified 14 Ulmus taxa which have not hitherto been reported as damaged by $A$. leucopoda. These are as follows: U. castaneifolia, U. glabra 'Camperdownii', $U$. glabra 'Exoniensis', U. glabra 'Horizontalis', U. glaucescens, $U$. lamellosa, $U$. minor var. vulgaris, $U$. minor 'Dampieri', U. minor 'Jacqueline Hillier', U. minor 'Umbraculifera', U. minor 'Variegata', U. minor 'Wredei', $U$. rubra 'Mauro' and Ulmus 'Lobel'. The affected Ulmus castaneifolia, U. glaucescens, U. lamellosa and U. rubra seem to be new records also at the species level. (Ulmus glaucescens was labelled on the spot as $U$. glaucescens var. lasiocarpa, however, in the lack of fruits, we could not confirm the identity of the variety). We have identified the Dutch complex hybrid cultivar Ulmus 'Lobel' $[(U$. wallichiana $\times$ U. glabra 'Exoniensis') $\times$ Ulmus $\times$ hollandica 'Bea Schwarz'] also as susceptible to the pest. We could observe significant damage (partial defoliation) only at the following locations (the taxon concerned is in brackets): Kecskeméti Arborétum (U. minor 'Variegata'), Növényi Diverzitás Központ (U. pumila var. arborea) and Tiszakürti Arborétum (U. pumila var. arborea). In all the other cases the damage was only moderate or rather insignificant.

\section{DISCUSSION}

Arboretums and botanical gardens proved to be appropriate sites for monitoring the occurrence of $A$. leucopoda as well as for studying the range of Ulmus taxa potentially affected by the pest. However, we have to note that even though the taxon name on the label of a plant is often informative it might also be misleading, therefore the recording of data from the labels should be completed with further identification based on collected plant samples and by using relevant keys.

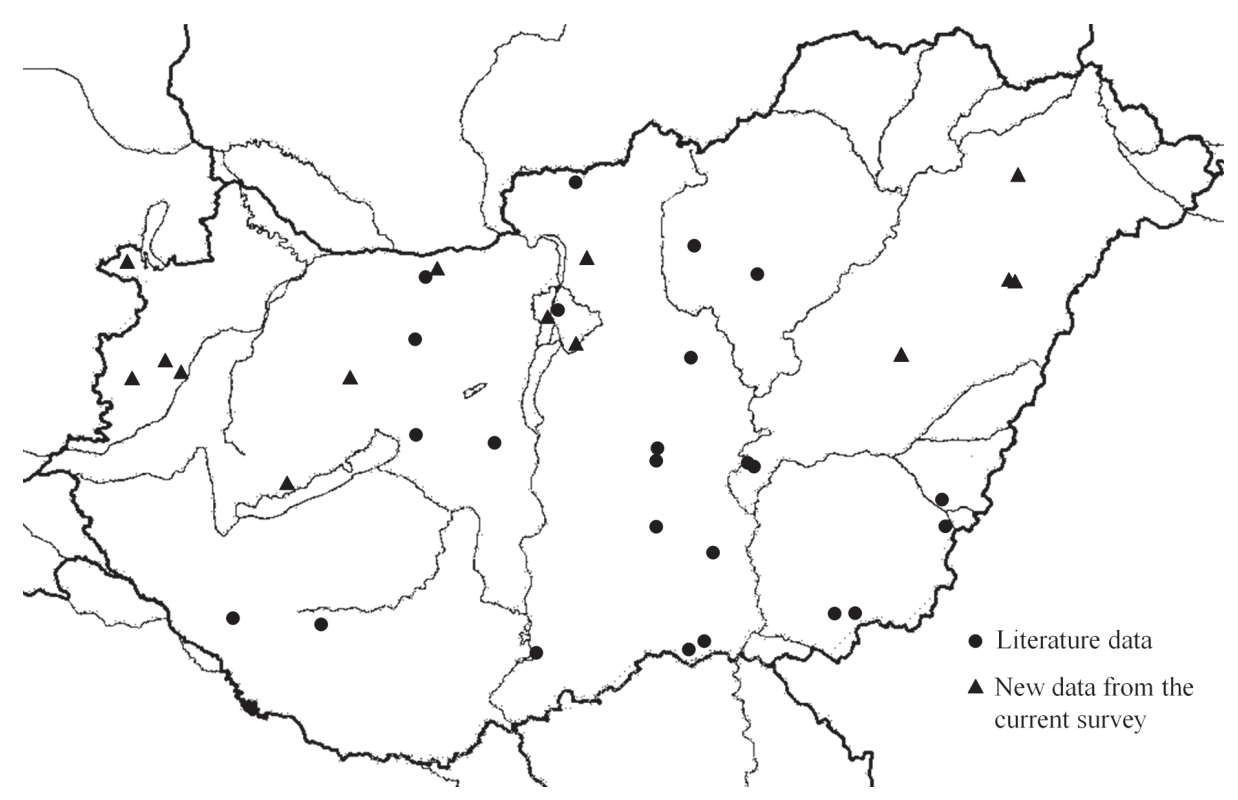

Figure 1. Distribution of A. leucopoda in Hungary. The map shows the presence records known from papers published until 2017 (1, 2, 4, 16, $42,43,44,45)$ (black dots) and the new records from the current survey (black triangles). 
Table 2. Detailed data on the occurrence of A. leucopoda in arboretums and botanical gardens of Hungary and the Ulmus taxa found damaged during the survey.

\begin{tabular}{|c|c|c|c|c|}
\hline $\begin{array}{l}\text { Name of the arboretum } \\
\text { or botanical garden }\end{array}$ & Coordinates & $\begin{array}{l}\text { Damaged Ulmus } \\
\text { taxon/taxa identified }\end{array}$ & $\begin{array}{l}\text { Developmental stage and/or } \\
\text { symptom }(s) \text { found }\end{array}$ & Date of record \\
\hline Agostyáni Arborétum & $\begin{array}{l}47.6554^{\circ} \mathrm{N} \\
18.4189^{\circ} \mathrm{E}\end{array}$ & U. glabra & feeding trace, empty cocoon & 31 July 2011 \\
\hline Budai Arborétum & $\begin{array}{l}47.4825^{\circ} \mathrm{N} \\
19.0399^{\circ} \mathrm{E}\end{array}$ & U. pumila var. arborea ${ }^{2}$ & feeding trace & 08 Sept. 2011 \\
\hline $\begin{array}{l}\text { Debreceni Egyetem } \\
\text { Botanikus Kert }\end{array}$ & $\begin{array}{l}47.5584^{\circ} \mathrm{N} \\
21.6205^{\circ} \mathrm{E}\end{array}$ & U. pumila var. arborea & feeding trace, empty cocoon & 15 Aug. 2011 \\
\hline $\begin{array}{l}\text { Diószegi Sámuel } \\
\text { Botanikus Kert }\end{array}$ & $\begin{array}{l}47.5593^{\circ} \mathrm{N} \\
21.6063^{\circ} \mathrm{E}\end{array}$ & $\begin{array}{l}\text { U. lamellosa, } \\
\text { U. minor 'Jacqueline Hillier' }\end{array}$ & feeding trace & 15 Aug. 2011 \\
\hline $\begin{array}{l}\text { Folly Arborétum és } \\
\text { Borászat }\end{array}$ & $\begin{array}{l}46.8107^{\circ} \mathrm{N} \\
17.5473^{\circ} \mathrm{E}\end{array}$ & U. minor var. vulgaris & feeding trace & 30 July 2011 \\
\hline Kámoni Arborétum & $\begin{array}{l}47.2564^{\circ} \mathrm{N} \\
16.6078^{\circ} \mathrm{E}\end{array}$ & Ulmus $\times$ hollandica & feeding trace & 29 July 2011 \\
\hline Kecskeméti Arborétum & $\begin{array}{l}46.9129^{\circ} \mathrm{N} \\
19.6515^{\circ} \mathrm{E}\end{array}$ & $\begin{array}{l}\text { U. glabra 'Camperdownii', } \\
\text { U. glabra 'Horizontalis', } \\
\text { U. minor 'Umbraculifera', } \\
\text { U. minor 'Variegata', } \\
\text { U. minor 'Wredei', } \\
\text { U. pumila var. arborea }\end{array}$ & $\begin{array}{l}\text { feeding trace, also larva on the } \\
\text { second taxon }\end{array}$ & 14 July 2011 \\
\hline $\begin{array}{l}\text { Nemzeti Botanikus } \\
\text { Kert, Vácrátót }\end{array}$ & $\begin{array}{l}47.7099^{\circ} \mathrm{N} \\
19.2319^{\circ} \mathrm{E}\end{array}$ & $\begin{array}{l}\text { U. castaneifolia, } \\
\text { U. davidiana var. japonica, } \\
\text { U. glabra 'Exoniensis', } \\
\text { U. glabra 'Horizontalis', } \\
\text { Ulmus 'Lobel', } \\
\text { U. minor 'Dampieri', } \\
\text { U. minor 'Umbraculifera', } \\
\text { U. rubra 'Mauro' }\end{array}$ & $\begin{array}{l}\text { feeding trace, also larva on the } \\
\text { second, forth, fifth and sixth } \\
\text { taxon, feeding trace and empty } \\
\text { cocoon on the first and seventh } \\
\text { taxon }\end{array}$ & 09 Aug. 2016 \\
\hline $\begin{array}{l}\text { Növényi Diverzitás } \\
\text { Központ }\end{array}$ & $\begin{array}{l}47.3565^{\circ} \mathrm{N} \\
19.8921^{\circ} \mathrm{E}\end{array}$ & U. pumila var. arborea & feeding trace, empty cocoon & 17 Aug. 2011 \\
\hline $\begin{array}{l}\text { Nyugat-magyarországi } \\
\text { Egyetem, Egyetemi Élő } \\
\text { Növénygyűjtemény }\end{array}$ & $\begin{array}{l}47.6799^{\circ} \mathrm{N} \\
16.5733^{\circ} \mathrm{E}\end{array}$ & $\begin{array}{l}\text { U. glaucescens, } \\
\text { U. minor var. vulgaris }\end{array}$ & feeding trace ${ }^{3}$ & $\begin{array}{l}19 \text { July } 2016 \\
\text { (first taxon), } \\
28 \text { July } 2011 \\
\text { (second taxon) }\end{array}$ \\
\hline $\begin{array}{l}\text { Püspökladány- } \\
\text { Farkasszigeti Arborétum }\end{array}$ & $\begin{array}{l}47.3356^{\circ} \mathrm{N} \\
21.0919^{\circ} \mathrm{E}\end{array}$ & $\begin{array}{l}\text { Ulmus } \times \text { hollandica, } \\
\text { U. pumila var. arborea }\end{array}$ & $\begin{array}{l}\text { feeding trace, also empty cocoon } \\
\text { on the second taxon }\end{array}$ & 17 Aug. 2011 \\
\hline Sárvári Arborétum & $\begin{array}{l}47.2531^{\circ} \mathrm{N} \\
16.9388^{\circ} \mathrm{E}\end{array}$ & U. minor var. vulgaris & feeding trace, pupa in cocoon & 28 July 2011 \\
\hline $\begin{array}{l}\text { Soroksári Botanikus } \\
\text { Kert }^{4}\end{array}$ & $\begin{array}{l}47.4003^{\circ} \mathrm{N} \\
19.1543^{\circ} \mathrm{E}\end{array}$ & U. pumila var. arborea & larva, feeding trace & 04 July 2011 \\
\hline Szelestei Arborétum & $\begin{array}{l}47.3071^{\circ} \mathrm{N} \\
16.8274^{\circ} \mathrm{E}\end{array}$ & U. minor var. minor & feeding trace, empty cocoon & 29 July 2011 \\
\hline Tiszakürti Arborétum & $\begin{array}{l}46.8920^{\circ} \mathrm{N} \\
20.1239^{\circ} \mathrm{E}\end{array}$ & $\begin{array}{l}\text { U. laevis, } \\
\text { U. pumila var. arborea }\end{array}$ & $\begin{array}{l}\text { feeding trace, also empty cocoon } \\
\text { on the second taxon }\end{array}$ & 19 Aug. 2011 \\
\hline $\begin{array}{l}\text { Tuzson János Botanikus } \\
\text { Kert }\end{array}$ & $\begin{array}{l}47.9739^{\circ} \mathrm{N} \\
21.7110^{\circ} \mathrm{E}\end{array}$ & U. pumila var. arborea & feeding trace, empty cocoon & 16 Aug. 2011 \\
\hline $\begin{array}{l}\text { Zirci Ciszterci } \\
\text { Arborétum }\end{array}$ & $\begin{array}{l}47.2617^{\circ} \mathrm{N} \\
17.8795^{\circ} \mathrm{E}\end{array}$ & $\begin{array}{l}\text { U. glabra, } \\
\text { U. minor 'Jacqueline Hillier' }\end{array}$ & $\begin{array}{l}\text { feeding trace, also empty cocoon } \\
\text { on the first taxon }\end{array}$ & 27 July 2011 \\
\hline
\end{tabular}

${ }^{1}$ Simply the live stage of and/or the typical symptom(s) by A. leucopoda we found are named without indicating exact numbers of them, therefore no plural forms are used here

${ }^{2}$ The solitary tree has been cut since our survey

${ }^{3}$ We could also observe a larva and an empty cocoon of the pest on two unidentified Ulmus trees in the botanical garden

${ }^{4}$ Information with photos were sent by G. Bottlik 
Our results confirm earlier findings that $A$. leucopoda is associated with both exotic and native Ulmus taxa. The new damaged cultivar or variety records we collected are less surprising in the cases of $U$. glabra and $U$. minor (i.e. these taxa belong to the already known host plant species of $A$. leucopoda - see Table 1). Nevertheless, the revealed susceptibility of the very popular cultivars, such as $U$. glabra 'Camperdownii' or U. minor 'Wredei' (33), may be a major matter of concern in horticulture. The suitability for egg laying of any of the taxa we identified during this study and their sensitivity to at least partial damage by the sawfly species may be suggested being taken into consideration when their use is planned for ornamental purposes, landscape design or in breeding programs. For example, $U$. pumila (var. arborea), an already known preferred host of $A$. leucopoda (Table 1), which is extremely adaptable to unfavorable climate and soil conditions (33), and hence is widely planted in Hungary, and which is amongst the best known and most used species in breeding for resistance to Dutch elm disease (46), has been found also in our survey as having suffered significant damage in several cases. However, the actual vulnerability and host status of all the studied taxa still needs to be investigated. It remains unknown why the larvae of $A$. leucopoda were not found on damaged leaves in spite of the presence of a short feeding trace. We found no evidence of the disappearance of larvae. We do not know if it was the result of the Ulmus taxa concerned having proved unsuitable for larval development after a while for any reasons, or just because of a heavy rain having knocked off the larvae (as it was observed by us in one case in a group of container $U$. pumila var. arborea plants infested previously by larvae of the pest), or due to predation etc. In the cases of the absence of live stages of $A$. leucopoda, the "identification" based only on the characteristic feeding pattern (and empty cocoons) might involve some uncertainty regarding the causal agent. However, we did not find any information on any other insect species which might be responsible for the same type of symptoms on elm leaves (cf. 31, 32). We think that until no insect species is reported to occur and cause the same symptoms on leaves of elms in Hungary, our records may be accepted as confirmations of the occurrence of and feeding damage by the zigzag elm sawfly. Our data collection method was, nevertheless, similar to that described by Blank et al. (19) for the same species.

Finally, we may suggest that any elm taxa, including the newly reported damaged ones, should be studied in more details under adequately controlled conditions to determine their actual vulnerability to $A$. leucopoda, especially if the taxon was intended to plant on a large scale in environments of a risk of known or facing presumably or potentially high pest pressure.

Acknowledgements: We are grateful to the management and staff of all the visited arboretums and botanical gardens for their assistance during our work. Special thanks are due to Géza Kósa, György Tihanyi, Mónika Vörösváczki and György Csóka for valuable consultations.

This paper was supported by the Jannos Bolyai Research Scholarship of the Hungarian Academy of Sciences, and by the COST Action TD1209, European Information System for Alien Species.

\section{REFERENCES}

1. BLANK SM, HARA H, MIKULÁS J, CSÓKA GY, CIORNEI C, CONSTANTINEANU R, CONSTANTINEANU I, ROLLER L, ALTENHOFER E, HUFLEJT T, VÉTEK G 2010 Aproceros leucopoda (Hymenoptera: Argidae): An East Asian pest of elms (Ulmus spp.) invading Europe. Eur J Entomol 107: 357-367. https://doi.org/10.14411/eje.2010.045

2. VÉTEK G, PAPP V, FAIL J, LADÁNYI M, BLANK SM 2016 Applicability of coloured traps for the monitoring of the invasive zigzag elm sawfly, Aproceros leucopoda (Hymenoptera: Argidae). Acta Zool Acad Sci H 62 (2): 165-173. https://doi.org/10.17109/AZH.62.2.165.2016

3. Boevé J-L 2013 First record in Belgium of the invasive sawfly Aproceros leucopoda (Hymenoptera : Argidae) and some related ecological data. Bulletin de la Société royale belge d'Entomologie / Bulletin van de Koninklijke Belgische Vereniging voor Entomologie 149: 217-221

4. VÉTEK G, MIKULÁS J, CSÓKA GY, BLANK SM 2010 A kanyargós szillevéldarázs (Aproceros leucopoda Takeuchi, 1939) Magyarországon. [The zigzag elm sawfly (Aproceros leucopoda Takeuchi, 1939) in Hungary.] Növényvédelem 46 (11): 519-521 [in Hungarian]

5. EISEMAN CS 2015 On the distinctive feeding pattern of Sterictiphora Billberg (Hymenoptera: Argidae) sawfly larvae. Proc Entomol Soc Wash 117 (1): 65-67.

https://doi.org/10.4289/0013-8797.117.1.65

6. CSÓKA GY, HIRKA A, SZŐCS L 2012 Rovarglobalizáció a magyar erdőkben. [Insect globalization in the Hungarian forests.] Erdészettudományi Közlemények 2 (1): 187-198 [in Hungarian]

7. CSÓKA GY, AMBRUS A 2016 Erdei fa- és cserjefajok szerepe a herbivor rovarok fajgazdagságának fenntartásában. [Role of forest woody plants in maintaining species richness of herbivore insects.] Pp 155-192. In: Korda M (ed) Az erdőgazdálkodás hatása az erdők biológiai sokféleségére. [Influence of forest management on the biodiversity of forests.] Tanulmánygyüjtemény. Duna-Ipoly Nemzeti Park Igazgatóság, Budapest, 679 pp [in Hungarian]

8. GNINENKO YUI, GNINENKO MYU, RAKOV AG $2013 \mathrm{New}$ detections of Aproceros leucopoda in Russia. Zashchita i karantin rasteniy 3: 40-41 [in Russian]

9. LENGESOVA NA 2012 Elm sawfly (Aproceros leucopoda Takeuchi, 1939) - new to the territory of Ulyanovsk Region pest of elm. Priroda Simbirskogo Povolzh'ya 13: 136-139 [in Russian]

10. LENGESOVA NA, MISHCHENKO AV 2013 Biology, ecology and molecular characterization of Aproceros leucopoda (Takeuchi, 1939) (Hymenoptera: Argidae), pest of elms in the Middle Volga Region. Caucasian Entomological Bull 9 (1): 163-167 [in Russian]

11. MARTYNOV VV, NIKULINA TV 2016 New invasive phytophagous insects in woods and forest plantings of Donbass. Caucasian Entomological Bull 12 (1): 41-51 [in Russian]

12. MARTYNOV VV, NIKULINA TV 2017 Population surge of zigzag elm sawfly (Aproceros leucopoda (Takeuchi, 1939): Hymenoptera: Argidae) in northern Sea of Azov region. Russian Journal of Biological Invasions 1: 25-34 [in Russian]. https://doi.org/10.1134/s2075111717020059 
13. SHCHUROV VI, GNINENKO YUI, LENGESOVA NA, GNINENKO MYU 2012 Elm sawfly in the European part of Russia. Zashchita i karantin rasteniy 2: 37-39 [in Russian]

14. SOROKIN NS 2013 Elm sawfly in the Rostov region. Zashchita i karantin rasteniy 11: 35-37 [in Russian]

15. TIMUŞ A, DERJANSCHI V, CROITORU N 2008 Viespea neagră a ulmului (Arge sp.) în Republica Moldova şi dezvoltarea acesteia pe ulmul de câmp - Ulmus minor. [Black wasp of elm (Arge sp.) in the Republic of Moldova and its development on field elm - Ulmus minor.] Mediul Ambiant 4 (40): 35-37 [in Romanian]

16. VÉTEK G, LOVAS M, CSÓKA GY 2012 A kanyargós szillevéldarázs (Aproceros leucopoda) 2011-ben ismert elterjedése és kártétele Magyarországon. [Distribution of zigzag elm sawfly (Aproceros leucopoda) and damage caused by the pest in Hungary in 2011.] $\mathrm{P}$ 86. In: Kőmíves T, Haltrich A, Molnár J (eds) Növényvédelmi Tudományos Napok 2012. Magyar Növényvédelmi Társaság, Budapest, 103 pp [in Hungarian]

17. WU XY 2006 Studies on the biology and control of Aproceros leucopoda. Plant Protection (Beijing) 32 (4): 98-100 [in Chinese]

18. ZANDIGIACOMO P, CARGNUS E, VILLANI A 2011 First record of the invasive sawfly Aproceros leucopoda infesting elms in Italy. B Insectol 64 (1): 145-149

19. BLANK SM, KÖHLER T, PFANNENSTILL T, NEUENFELDT N, ZIMMER B, JANSEN E, TAEGER A, LISTON AD 2014 Zig-zagging across Central Europe: recent range extension, dispersal speed and larval hosts of Aproceros leucopoda (Hymenoptera, Argidae) in Germany. J Hymenopt Res 41: 57-74. https://doi.org/10.3897/JHR.41.8681

20. WU X-Y, XIN H 2006: A new recorded species of the genus Aproceros Malaise (Hymenoptera: Argidae) from China. Entomotaxonomia 28 (4): 279-280 [in Chinese]

21. DE GROOT M, HAUPTMAN T, SELJAK G 2012 Prva najdba invazivne brestove grizlice, Aproceros leucopoda (Hymenoptera: Argidae) v Sloveniji. [The first record of the invasive "zigzag« sawfly Aproceros leucopoda (Hymenoptera: Argidae) in Slovenia.] Gozdarski vestnik 70 (1): 3-7 [in Slovenian]

22. GLAVENDEKIĆ M, PETROVIĆ J, PETAKOVIĆ M 2013 Alien invasive species Aproceros leucopoda Takeuchi (Hymenoptera: $\mathrm{Ar}-$ gidae) - elm pest in Serbia. Sumarstvo 1-2: 47-56 [in Serbian]

23. CSÓKA GY, HIRKA A, SZŐCS L, SZABÓKY CS 2012 Newest uninvited insect guests in the Hungarian forests. Forstschutz Aktuell 55: 30-31.

24. KRAUS M, LISTON AD, TAEGER A 2011 Die invasive ZickZack-Ulmenblattwespe Aproceros leucopoda Takeuchi, 1939 (Hymenoptera: Argidae) in Deutschland. [The invasive zig-zag elm sawfly, Aproceros leucopoda (Hymenoptera: Argidae) in Germany.] DGaaE-Nachrichten 25 (3): 117-119 [in German]

25. MOL AWM, VONK DH 2015 De iepenzigzagbladwesp Aproceros leucopoda (Hymenoptera, Argidae), een invasieve exoot in Nederland. [The 'ziczac' elm sawfly Aproceros leucopoda (Hymenoptera, Argidae), an invasive species in the Netherlands.] Entomologische Berichten 75 (2): 50-63 [in Dutch]

26. HOLUŠA J, STODU゚LKOVÁ P, MACEK J 2017 Observations on the occurrence and phenology of the invasive elm defoliator Aproceros leucopoda (Hymenoptera: Argidae) in the Czech Republic. Urban For Urban Gree 21: 29-33.

https://doi.org/10.1016/j.ufug.2016.11.005

27. DOYCHEV D 2015 First record of the invasive elm sawfly Aproceros leucopoda Takeuchi (Hymenoptera: Argidae) in Bulgaria. Silva Balcanica 16 (1): 108-112

28. MATOŠEVIĆ D 2012 Prvi nalaz brijestove ose listarice (Aproceros leucopoda), nove invazivne vrste u Hrvatskoj. [First record of elm sawfly (Aproceros leucopoda), new invasive species in Croatia.] Šumarski list 136 (1-2): 57-61 [in Croatian]

29. PRICOP E, CARDAŞ G, CIORNEI C, ANDRIESCU I 2012 On the egg parasitoids of Aproceros leucopoda (Hymenoptera: Argidae), an invasive pest species from Japan. ABAH Bioflux 4 (2): $43-46$

30. CSÓKA GY, HIRKA A 2011 Alien and invasive forest insects in Hungary (a review). Proceedings of the "Biotic Risks and Climate Change in Forests" $10^{\text {th }}$ IUFRO workshop of WP 7.03.10 "Methodology of Forest Insect and Disease Survey in Central Europe", September 20-23, 2010, Freiburg, Germany. Berichte Freiburger Forstliche Forschung 89: 54-60.

31. CSÓKA GY, HIRKA A, KOLTAY A, KOLOZS L 2013 Erdőkárok - képes útmutató. [Types of forest damage - a photographic field guide.] NÉBIH Erdészeti Igazgatósága - Erdészeti Tudományos Intézet, Budapest, 223 pp [in Hungarian]

32. ZÚBRIK M, KUNCA A, CSÓKA GY (eds) 2013 Insects and diseases damaging trees and shrubs of Europe. NAP Editions, Paris, $535 \mathrm{pp}$

33. MACKENTHUN G 2017 Handbuch der Ulmengewächse. Version 2.0. [Handbook of Ulmaceae. Version 2.0.]

www.ulmen-handbuch.de [accessed 25 January 2017] [in German]

34. ROLOFF A, BÄRTELS A 2008 Flora der Gehölze. 3. Auflage. [Manual of trees. 3. Edition.] Ulmer Verlag, Stuttgart, 912 pp [in German]

35. FU L, XIN Y, WHITTEMORE A 2003 Ulmaceae. Flora of China 5: $1-19$

36. BÄRTELS A, SCHMIDT PA (eds) 2014 Enzyklopädie der Gartengehölze. 2. Auflage. [Encyclopedia of cultivated woody plants. 2. Edition.] Ulmer Verlag, Stuttgart, 882 pp [in German]

37. BANNON L, HIPP A 2015 Elm cultivars checklist. The Morton Arboretum.

http://systematics.mortonarb.org/ulmus/ [accessed 25 January 2017]

38. SCHÜTT P, SCHUCK JH, LANG UM, WEISGERBER H, STIMM B, ROLOFF A (eds) 1994-2017 Enzyklopädie der Holzgewächse. Handbuch und Atlas der Dendrologie. [Encyclopedia of woody plants. Handbook and atlas of dendrology.] Ecomed Verlagsgesellschaft / Wiley-VCH, Landsberg, 5388 pp [in German]

39. THE INTERNATIONAL PLANT NAMES INDEX $2015 \mathrm{Pu}-$ blished on the Internet http://www.ipni.org [accessed 25 January 2017]

40. THE PLANT LIST 2013 Version 1.1. Published on the Internet; http://www.theplantlist.org/ [accessed 25 January 2017]

41. VÉTEK G, BARTHA D, OLÁH R 2016 Occurrence of the invasive zigzag elm sawfly (Aproceros leucopoda) in arboretums and botanical gardens of Hungary. $2^{\text {nd }}$ Croatian Symposium on invasive species, Zagreb, Croatia, 21-22. XI 2016. Book of Abstracts, p 63

42. HARIS A 2009 Sawflies of the Zselic Hills, SW Hungary (Hymenoptera: Symphyta). Nat Somogy 15: 127-158

43. HARIS A 2010 Sawflies of the Vértes Mountains (Hymenoptera: Symphyta). Nat Somogy 17: 221-250

44. HARIS A 2012 Sawflies of Belső-Somogy (Hymenoptera: Symphyta). Nat Somogy 22: 141-162

45. GYURKOVICS H, HARIS A 2012 Sawflies (Hymenoptera: Symphyta) from Szeged and its surroundings (SE Hungary). Nat Somogy 22: 163-182

46. MITTEMPERGHER L, SANTINI A 2004 The history of elm breeding. Invest Agrar: Sist Recur For 13 (1): 161-177 